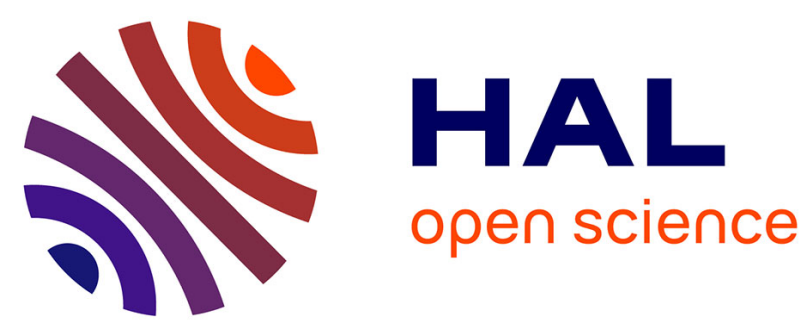

\title{
Plasma and exhaled breath condensate nitrite-nitrate level in relation to environmental exposures in adults in the EGEA study.
}

\author{
Marta Rava, Raphäelle Varraso, Brigitte Decoster, Hélène Huyvaert, Nicole
}

Le Moual, Bénédicte Jacquemin, Nino Künzli, Francine Kauffmann, Farid

Zerimech, Régis Matran, et al.

\section{To cite this version:}

Marta Rava, Raphäelle Varraso, Brigitte Decoster, Hélène Huyvaert, Nicole Le Moual, et al.. Plasma and exhaled breath condensate nitrite-nitrate level in relation to environmental exposures in adults in the EGEA study.. Nitric Oxide: Biology and Chemistry, 2012, 27 (3), pp.169-75. 10.1016/j.niox.2012.06.007 . inserm-00742527

\section{HAL Id: inserm-00742527 https://www.hal.inserm.fr/inserm-00742527}

Submitted on 16 Oct 2012

HAL is a multi-disciplinary open access archive for the deposit and dissemination of scientific research documents, whether they are published or not. The documents may come from teaching and research institutions in France or abroad, or from public or private research centers.
L'archive ouverte pluridisciplinaire HAL, est destinée au dépôt et à la diffusion de documents scientifiques de niveau recherche, publiés ou non, émanant des établissements d'enseignement et de recherche français ou étrangers, des laboratoires publics ou privés. 


\title{
Plasma and exhaled breath condensate nitrite-nitrate level in relation to environmental exposures in adults in the EGEA study
}

\author{
Marta Rava ${ }^{a, b}$, Raphäelle Varraso ${ }^{a, b}$, Brigitte Decoster ${ }^{c}$, Hélène Huyvaert ${ }^{c}$, Nicole Le Moual ${ }^{a, b}$, Bénédicte Jacquemin ${ }^{a, b}$, \\ Nino Künzli ${ }^{\mathrm{d}, \mathrm{e}}$, Francine Kauffmann ${ }^{\mathrm{a}, \mathrm{b}}$, Farid Zerimech ${ }^{\mathrm{f}}$, Régis Matran ${ }^{\mathrm{c}, \mathrm{f}}$, Rachel Nadif ${ }^{\mathrm{a}, \mathrm{b}}$ \\ ${ }^{a}$ Respiratory and Environmental epidemiology, CESP Centre for research in Epidemiology and Population health, U1018, Inserm, F- \\ 94807, 16, avenue Paul Vaillant Couturier, 94807 Villejuif, France \\ b Université Paris Sud 11, UMRS 1018, F-94807, avenue Paul Vaillant Couturier, 94807 Villejuif, France \\ ${ }^{c}$ Université Lille Nord de France, Faculté de Médecine - pôle Recherche Département de Physiologie, 1, place de Verdun, 59045 Lille \\ Cédex, France \\ ${ }^{d}$ Swiss Tropical and Public Health Institute, Socinstr. 57, P.O. Box, 4002 Basel Switzerland \\ ${ }^{\mathrm{e}}$ University of Basel, Petersplatz 1, CH-4003 Basel, Switzerland
}

${ }^{f} \mathrm{CHU}, \mathrm{Bd}$ Pr Leclercq 59037, Lille, France

E-mail address for co-authors:

Raphäelle Varraso: raphaelle.varraso@inserm.fr, Brigitte

Decoster: bdecoster@univ-lille2.fr, Hélène

Huyvaert: huyvaert.helene@voila.fr, Nicole Le Moual:

nicole.lemoual@inserm.fr, Bénédicte Jacquemin:

benedicte.jacquemin@inserm.fr, Nino Künzli:

nino.kuenzli@unibas.ch, Francine Kauffmann:

francine.kauffmann@inserm.fr, Farid Zerimech

Farid.ZERIMECH@CHRU-LILLE.FR, Régis Matran:

regis.matran@CHRU-LILLE.FR, Rachel Nadif:

Rachel.nadif@inserm.fr

\section{Corresponding author: Marta Rava}

Address: Epidémiologie respiratoire et environnementale, CESP/UMRS 1018 Inserm - UPS11

16, avenue Paul Vaillant Couturier, 94807 Villejuif

Fax: 33 (0) 1455951 69, phone: 33 (0) 145595358

E-mail: marta.rava@inserm.fr

\section{List of abbreviations}

$\mathrm{Cl}$, confidence interval; EBC, Exhaled breath condensate; EGEA, Epidemiological study on Genetics and Environment of Asthma; FeNO, fraction of exhaled nitric oxide; $\mathrm{NO}$, Nitric Oxide; $\mathrm{NO}_{2}{ }^{-}$, Nitrite; $\mathrm{NO}_{3}{ }^{-}$, Nitrate; $\mathrm{NO}_{2}$, Nitrogen dioxide; $\mathrm{O}_{3}$, Ozone; $\mathrm{PM}_{10}$ Particulate Matter with aerodynamic diameter $\leq 10 \mu \mathrm{m}$; $\mathrm{Q}$, quartile

\section{Abstract}

This study evaluated the associations between biological markers in the nitrate-nitrite-NO pathway and four environmental exposures among subjects examined in the second survey (2003-2007) of the French Epidemiological study on Genetics and Environment of Asthma (EGEA). Total nitrite and nitrate $\left(\mathrm{NO}_{2}{ }^{-} / \mathrm{NO}_{3}{ }^{-}\right)$levels were measured both in plasma and in exhaled breath condensate (EBC) in 949 adults. Smoking, diet and exposure to chlorine products were assessed using standardized questionnaires. Exposure to air pollutants was estimated by using geostatistical models. All estimates were obtained with generalized estimating equations for linear regression models. Median levels of $\mathrm{NO}_{2}{ }^{-} / \mathrm{NO}_{3}{ }^{-}$were $36.3 \mu \mathrm{M}\left(1^{\text {st }}-3^{\text {rd }}\right.$ quartile: $\left.25.7,51.1\right)$ in plasma and $2.0 \mu \mathrm{mol} / \mathrm{mg}$ proteins $\left(1^{\text {st }}-3^{\text {rd }}\right.$ quartile $\left.0.9,3.9\right)$ in EBC. After adjustment for asthma, age, sex and menopausal status, plasma $\mathrm{NO}_{2}{ }^{-} / \mathrm{NO}_{3}{ }^{-}$ level increased with leafy vegetable consumption (above versus below median $=0.04(95 \% \mathrm{Cl}: 0.001,0.07))$ and decreased in smokers (versus non/ex-smokers $=-0.08(95 \% \mathrm{Cl}$ : $-0.11,-0.04)$. EBC $\mathrm{NO}_{2}{ }^{-} / \mathrm{NO}_{3}{ }^{-}$level decreased in smokers ($0.08(95 \% \mathrm{Cl}:-0.16,-0.001))$ and with exposure to ambient $\mathrm{O}_{3}$ concentration (above versus below median $=-0.10(95 \% \mathrm{Cl}$ :$0.17,-0.03)$ ). Cured meat, chlorine products, $\mathrm{PM}_{10}$ and $\mathrm{NO}_{2}$ concentrations were not associated with $\mathrm{NO}_{2}{ }^{-} / \mathrm{NO}_{3}^{-}$levels. Results suggest that potential modifiable environmental and behavioral risk factors may modify $\mathrm{NO}_{2}{ }^{-} / \mathrm{NO}_{3}{ }^{-}$levels in plasma and $\mathrm{EBC}$ according to the route of exposure.

Keywords: Air pollutants, Biological markers, Chlorine, Diet, Nitrate, Nitrites, Tobacco smoke

\section{INTRODUCTION}

Known biological markers involved in the nitrosative pathway, also called the "nitrate-nitrite-nitric oxide" pathway, are nitric oxide (NO), nitrites $\left(\mathrm{NO}_{2}{ }^{-}\right)$and nitrates $\left(\mathrm{NO}_{3}{ }^{-}\right)$, which are indirect stable indicators of $\mathrm{NO}$ synthesis. These biological markers play a key role in several physiological functions ranging from neuromodulation to regulation of vascular tone [1], and are involved in local host defense, gut mucosa integrity and also in cardiovascular [2] and airway diseases [3]. Pharmacological and dietary interventions on prevention and treatment of diseases are now under study [4]. Until now, epidemiological studies have been mainly conducted on the fraction of exhaled NO (FeNO). Diet is the most important source of both $\mathrm{NO}_{2}{ }^{-}$(mostly from cured meats) and $\mathrm{NO}_{3}{ }^{-}$ (mostly from leafy vegetables) [5]. Formation of $\mathrm{NO}_{2}{ }^{-}$and $\mathrm{NO}_{3}{ }^{-}$ can also take place after inhalation of exogenous compounds like oxidants from cigarette smoke $[6 ; 7]$, nitrogen dioxide $\left(\mathrm{NO}_{2}\right)$ and ozone $\left(\mathrm{O}_{3}\right)$ from air pollution [8], and chlorine from cleaning agents [9] .

The negative association between exposure to tobacco smoke and FeNO is well known [10], while the association between FeNO with other environmental exposures has been explored more in children [11; 12] than in adults [13]. However, few epidemiological and clinical studies have focused on the associations between environmental exposures and $\mathrm{NO}_{2}{ }^{-} / \mathrm{NO}_{3}{ }^{-}$. In the occupational setting, Gube et al [14] reported that welders had high $\mathrm{NO}_{3}{ }^{-}$concentrations, and Ghasemi et al [15] found increasing serum $\mathrm{NO}_{2}{ }^{-} / \mathrm{NO}_{3}{ }^{-}$levels in smokers compared to non- and ex-smokers.

In biological fluids, the half-life of nitric oxide (NO) is extremely short owing to its rapid oxidation to nitrites $\left(\mathrm{NO}_{2}^{-}\right)$and nitrates $\left(\mathrm{NO}_{3}{ }^{-}\right)$[16]. Total $\mathrm{NO}_{2}{ }^{-} / \mathrm{NO}_{3}{ }^{-}$levels are usually measured in blood (plasma or serum) but can also be measured in exhaled breath condensate (EBC). Interest in the analysis of EBC constituents has increased in the last ten years, because EBC is viewed as a promising tool for non-invasive evaluation of lung diseases [17]. As plasma and EBC are two distinct body constituents, we hypothesized that direct or indirect environmental sources of $\mathrm{NO}_{2}^{-}$and $\mathrm{NO}_{3}^{-}$might have differential effects on $\mathrm{NO}_{2}{ }^{-} / \mathrm{NO}_{3}{ }^{-}$levels in plasma and $\mathrm{EBC}$. Production of $\mathrm{NO}_{2}{ }^{-} / \mathrm{NO}_{3}{ }^{-}$in plasma is more complex than in EBC. In the latter, ionized $\mathrm{NO}_{3}{ }^{-}$and $\mathrm{NO}_{2}{ }^{-}$(not volatile) may be produced from NO after reaction with oxygen [18] or from activated immune cells present in the lining of the lungs [19]. In plasma, $\mathrm{NO}_{2}{ }^{-} / \mathrm{NO}_{3}{ }^{-}$production derives from several sources, such as bacteria, enzymatic production and dietary sources [16]. To clarify the role of environmental exposures on levels of biological markers in the nitrosative pathway, associations between smoking, dietary habits, ambient air pollution, and chlorine products with total $\mathrm{NO}_{2}{ }^{-} / \mathrm{NO}_{3}{ }^{-}$level both in plasma and EBC were evaluated in adults from the Epidemiological study on the Genetics and Environment of Asthma (EGEA).

\section{MATERIALS AND METHODS}

2.1. Study population

Data used for the analyses were collected in the framework of the 12-year follow-up of the EGEA study (http://cesp.vjf.inserm.fr/egeanet/). The EGEA study has been 
described elsewhere [20; 21]. Briefly, it combines a casecontrol study with a family study of asthma cases (children or adults) conducted between 1991 and 1995 in 2047 subjects from five French cities. A follow-up of the initial cohort was conducted between 2003 and 2007 [22]. Among the alive cohort $(n=2002), 92 \% \quad(n=1845)$ completed a short selfadministered questionnaire and among them 1601 had a complete examination. The present project includes those who were adults at the second survey ( $\geq 16$ years old, $n=1570$ adults) with available measurement of total $\mathrm{NO}_{2}{ }^{-} / \mathrm{NO}_{3}{ }^{-}$levels both in plasma and EBC $(n=949)$. Subjects included in the analyses were more exposed to $\mathrm{O}_{3}$ and less to $\mathrm{NO}_{2}$ than those not included in the analyses $(n=621)$, and the two groups were similar for age, sex, asthma status and for the other environmental exposures considered. Asthmatics were defined by a positive answer to either "have you ever had attacks of breathlessness at rest with wheezing" or, "have you ever had asthma attacks?" or if they were recruited as asthma cases at the initial survey. Ethical approval was obtained from the relevant institutional review board committees (Cochin PortRoyal Hospital and Necker-Enfants Malades Hospital, Paris) and written consent was signed by all participants.

\subsection{Biological measurements}

EBC was collected with an RTube (TM) according to standardized methods. Briefly, the RTube (TM) was rinsed with deionized water and dried thoroughly. Subjects breathed orally at tidal volumes into a mouthpiece attached to a cold condenser $\left(-20^{\circ} \mathrm{C}\right)$. The patient was seated comfortably with a headrest. All headrests and back seatseats were tilted slightly to avoid any saliva contamination during breathing maneuvers. Breathing was quiet and regular. After 15 minutes, EBC collection was immediately separated in aliquots and stored at $-80 \cdot \mathrm{C}$ according to standardized procedures (http://www.afaq.org/certification=262711141114). Plasma aliquots were stored from 1.7 to 5.3 years and EBC samples from 1.8 to 5.4 years until analysis.

Total $\mathrm{NO}_{2}{ }^{-} / \mathrm{NO}_{3}{ }^{-}$levels were measured in plasma and $\mathrm{EBC}$ by the Griess reaction [23]. Briefly, $\mathrm{NO}_{3}{ }^{-}$was reduced to $\mathrm{NO}_{2}{ }^{-}$by adding $\mathrm{NO}_{3}{ }^{-}$reductase $(25 \mathrm{mU} / \mathrm{ml})$ and $\mathrm{NADPH} 20 \mathrm{mM}$ at room temperature. After 3 hours, samples were deproteinized by adding a solution of $\mathrm{ZNSO}_{4} 30 \%$ and centrifuged. Griess reagent $(0.1 \%$ naphthalethylene-dimine and 1 sulfanilamide in $\left.5 \% \mathrm{H}_{3} \mathrm{PO}_{4}\right)$ was added to supernatants. The optical density at $560 \mathrm{~nm}$ was measured using a microplaque reader. $\mathrm{NO}_{2}{ }^{-}$ levels were calculated by comparison with optical density 560 of standard sodium $\mathrm{NO}_{2}{ }^{-}$solutions. All measurements were done in duplicate. Analytical intra-run imprecision was below $3 \%$. Measurements with a coefficient of variation $>15 \%$ and extreme outliers $(n=7)$ were excluded from the analyses. Protein concentration in EBC was determined according to Smith [24]. Total $\mathrm{NO}_{2}{ }^{-} / \mathrm{NO}_{3}{ }^{-}$level levels were expressed as $\mu \mathrm{M}$ in plasma and as $\mu \mathrm{mol} / \mathrm{mg}$ of proteins in EBC [25].

In 116 out of 120 subjects chosen at random, $\mathrm{NO}_{2}{ }^{-}$levels were measured by the Griess reaction before and after adding $\mathrm{NO}_{3}{ }^{-}$ reductase. $\mathrm{NO}_{3}{ }^{-}$levels were obtained as the difference between total $\mathrm{NO}_{2}{ }^{-} / \mathrm{NO}_{3}{ }^{-}$and $\mathrm{NO}_{2}{ }^{-}$levels.

\subsection{Environmental exposures \\ 2.3.1. Smoking status.}

'Current smokers' were individuals who reported currently smoking at the time of the study and for at least one year, while 'ex-smokers' were those who stopped smoking for at least four weeks. Subjects were grouped as: 'no/ex-smokers' and 'current smokers'. Daily tobacco consumption was evaluated considering 1 cigarette, 1 cigarillo and 1 cigar as equal to 1,2 and $5 \mathrm{~g}$ respectively.

\subsubsection{Dietary assessment}

Dietary consumption of cured meat and leafy vegetables was obtained by using a food frequency questionnaire designed to assess average food intake during the previous 12 months. This questionnaire was set up based on a validated French dietary questionnaire [26]. Participants indicated their average frequency of consumption for 118 items including meat and vegetables over the past year in terms of the specified serving size by checking one of eight frequency categories ranging from 'never or $<1$ time/month' to '>= 4 times/day'. Standard portion sizes were listed with each food. The selected frequency category for each food item was converted to a daily intake. Cured meat consumption was defined as the sum of the intake for sausage (portion size, 1 piece) and dried sausage (portion size, 2 slices). Leafy vegetable consumption was defined as the sum of the intake for salad, raw or cooked endives, raw or cooked watercress, or cooked spinach. Those vegetables were considered because of the high content of nitrate. Intake of cured meats and leafy vegetables was divided into two categories defined by the median and was also used as continuous variable.

\subsubsection{Air pollution}

Yearly estimates of ambient air pollution concentrations were assigned at each participant's home address in 2004 for $\mathrm{O}_{3}$, $\mathrm{PM}_{10}$, and $\mathrm{NO}_{2}$. Estimates were developed by the French Institute of Environment using a geo-statistical interpolation model (cokriging-like integrating land cover and specific cofactors for each pollutant such as altitude $\left(\mathrm{O}_{3}\right)$, inventory of nitrogen oxides emissions, road network and population density $\left(\mathrm{NO}_{2}\right)$, and inventory of black smoke emissions $\left.\left(P M_{10}\right)\right)$. Interpolation was performed for annual mean concentrations obtained from background monitoring stations on a $4 \mathrm{~km} \times 4 \mathrm{~km}$ grid covering the whole of France [27]. Air pollution concentrations were divided into two categories defined as above /below the median and were also analyzed as continuous variables.

\subsubsection{Exposure to chlorine products.}

Subjects were defined as exposed to chlorine products if they used detergents containing chlorine at work or at home. Occupational exposure to chlorine products was defined as exposure to bleach/chlorine at work during disinfecting or cleaning tasks in the last job. The use of chlorine products was evaluated on the basis of an expert assessment or by selfreport when no expert evaluation was available. In the EGEA survey, the validity of self-reported exposure to bleach/chlorine was good (Cohen's Kappa coefficient: 0.82 , sensitivity: $87 \%$, specificity: 95\%) [28]. Information about domestic exposure to cleaning agents was collected through a specific questionnaire previously used in the European Community Respiratory Health Survey [29]. A subject was considered as exposed at home if he/she declared using bleach/chlorine weekly.

\subsection{Statistical analysis}

Total $\mathrm{NO}_{2}{ }^{-} / \mathrm{NO}_{3}{ }^{-}$levels were log10-transformed as a result of their skewed distribution. Differences among groups were tested using Student's t-test, the Mann-Whitney $U$ test or the Chi-square test when appropriate. Heterogeneity among asthmatics and non-asthmatics adjusted on age was tested using a linear regression model for continuous variables and the Cochran-Mantel-Haenszel test of conditional independence for categorical variables. The Spearman correlation coefficient was used to estimate correlations between environmental exposures. Even though some of the variables were dichotomous, the Spearman correlation was judged an appropriate index because dichotomous variables are a special case of ordinal variables. In addition, the use of Spearman correlations allowed the results to be presented in a consistent format. The association between environmental exposures and total $\mathrm{NO}_{2}{ }^{-} / \mathrm{NO}_{3}{ }^{-}$levels was estimated with linear regression models. Parameter estimates were obtained by using generalized estimating equations, with an exchangeable working correlation to account for the potential clustering within the families (SAS MIXED procedure). Estimates were first adjusted for asthma. Since plasma $\mathrm{NO}_{2}{ }^{-} / \mathrm{NO}_{3}{ }^{-}$levels were higher in menopausal women (see section 3), the analyses were also adjusted for age and a 3class variable based on sex and menopausal status (men, premenopausal women and postmenopausal women). Interactions between environmental exposures and sex, age or asthma were studied when appropriate by including an interaction term in the linear model. The environmental exposures that showed an association with $\mathrm{P}<0.1$ with total plasma or $\mathrm{EBC} \mathrm{NO}_{2}{ }^{-} / \mathrm{NO}_{3}{ }^{-}$level were included in the final model with asthma, age, and menopausal status. As a sensitivity analysis, the analyses were repeated by considering 
only non-asthmatics. The level of statistical significance was set at $\alpha=0.05$. Two-sided P-values were reported for all association estimates. All analyses were conducted using SAS software, version 9.2 (Cary, NC, USA).

\section{RESULTS}

Characteristics of the 949 adults according to their asthma status and sex are summarized in Table 1. EBC $\mathrm{NO}_{2}{ }^{-} / \mathrm{NO}_{3}{ }^{-}$ levels did not vary with storage time and plasma $\mathrm{NO}_{2}{ }^{-} / \mathrm{NO}_{3}{ }^{-}$ slightly decreased with storage time (Beta for linear regression model=-0.03, $\mathrm{P}=0.03$ ).

Analysis of variations according to sex and 10-year age classes was first performed (see Figure A.1). It showed that women older than 45 years had higher total plasma $\mathrm{NO}_{2}{ }^{-} / \mathrm{NO}_{3}{ }^{-}$ levels ( $P$-value for interaction between age and sex: 0.02). Menopausal status was significantly related to higher plasma $\mathrm{NO}_{2}{ }^{-} / \mathrm{NO}_{3}{ }^{-}$levels (median $\left(1^{\text {st }}-3^{\text {rd }}\right.$ quartile $(\mathrm{Q})$ ): $34(24-47) \mu \mathrm{M}$ vs. 39 (28-59) $\mu \mathrm{M} ; \mathrm{P}<0.001)$. Men were more frequently smokers than women (Table 1). Cured meat consumption was higher in asthmatics than in non-asthmatics, and in males than in females. Women consumed more leafy vegetables and were more exposed to chlorine products than men. Asthmatics lived in areas with lower $\mathrm{NO}_{2}$ and $\mathrm{PM}_{10}$ and higher $\mathrm{O}_{3}$ ambient concentrations than non- asthmatics. Neither plasma nor EBC total $\mathrm{NO}_{2}{ }^{-} / \mathrm{NO}_{3}{ }^{-}$levels were associated with asthma status or with sex. No association was observed between $\mathrm{NO}_{2}{ }^{-} / \mathrm{NO}_{3}$ levels measured in plasma and EBC (Pearson $r=0.03$, $\mathrm{P}=0.30$ ).

Correlations between the four environmental exposures are shown in Table A.1. Current smokers consumed more cured meat than non/ex-smokers. Leafy vegetable consumption was positively associated with exposure to chlorine products. $\mathrm{NO}_{2}$ and $\mathrm{PM}_{10}$ concentrations were negatively correlated. Age was negatively associated with smoking habits and cured meat consumption and positively related with leafy vegetable consumption, exposure to chlorine products, ambient concentrations of $\mathrm{O}_{3}$ and $\mathrm{PM}_{10}$.

3.1. Total plasma $\mathrm{NO}_{2}{ }^{-} / \mathrm{NO}_{3}{ }^{-}$levels and environmental exposures

Total plasma $\mathrm{NO}_{2}{ }^{-} / \mathrm{NO}_{3}{ }^{-}$levels were lower in smokers than in non/ex-smokers and were negatively associated with daily grams of tobacco smoked (see Table 2, Figure A.2). Excluding the ex-smokers that quitted smoking since less than a month $(n=9)$ did not change the results. Higher levels of total $\mathrm{NO}_{2}{ }^{-} / \mathrm{NO}_{3}{ }^{-}$were observed in subjects who consumed high amounts of leafy vegetables (see Table 2, Figure A.2). In the subsample of 116 subjects in whom $\mathrm{NO}_{3}{ }^{-}$and $\mathrm{NO}_{2}{ }^{-}$levels were measured separately, $\mathrm{NO}_{3}{ }^{-}$median levels increased from 17.8 to $25.8 \mu \mathrm{M}$ for low to high consumers of leafy vegetables $(P=0.4)$. No statistically significant association was observed between total plasma $\mathrm{NO}_{2}{ }^{-} / \mathrm{NO}_{3}{ }^{-}$levels and cured meat consumption, chlorine products and ambient air pollutant concentrations (see Table 2 and Figure A.2). After adjustment for asthma, age, sex, and menopausal status, associations were confirmed between plasma $\mathrm{NO}_{2}{ }^{-} / \mathrm{NO}_{3}{ }^{-}$and smoking habits and daily grams of tobacco smoked, measured both as categorical and as continuous variables (results not shown). The association with leafy vegetable consumption measured as categorical variable was borderline significant (Table 2). When included in the same model, smoking status and leafy vegetables remained significantly associated with plasma $\mathrm{NO}_{2}{ }^{-} / \mathrm{NO}_{3}{ }^{-}$levels (see Table 4). Similar results were observed among non-asthmatics only and when storage time was included as covariate in the models (results not shown).

\subsection{Total EBC $\mathrm{NO}_{2}{ }^{-} / \mathrm{NO}_{3}{ }^{-}$levels and environmental} exposures

Total EBC $\mathrm{NO}_{2}{ }^{-} / \mathrm{NO}_{3}{ }^{-}$levels were lower in current smokers than in non/ex-smokers, were negatively associated with cured meat consumption and with exposure to $\mathrm{O}_{3}$ and were not associated with chlorine products, leafy vegetable consumption and $\mathrm{NO}_{2}$ concentration (Table 3 and Figure A.3). After adjustment for asthma, age, sex and menopausal status, the associations with smoking status, cured meat consumption and exposure to $\mathrm{O}_{3}$ were statistically significant (see Table 3).
When smoking status, cured meat consumption and exposure to $\mathrm{O}_{3}$ were included in the same model, the negative associations with $\mathrm{EBC} \mathrm{NO}_{2}{ }^{-} / \mathrm{NO}_{3}{ }^{-}$level remained statistically significant for smoking status and exposure to $\mathrm{O}_{3}$ (see Table 4). When air pollution concentration of $\mathrm{PM}_{10}$ and $\mathrm{O}_{3}$ were considered as continuous variables, both slopes were negative and statistically significant, and remained significant after adjustment for asthma, age, sex and menopausal status (results not shown). Total levels of EBC $\mathrm{NO}_{2}{ }^{-} / \mathrm{NO}_{3}{ }^{-}$decreased with high concentration levels of $\mathrm{PM}_{10}$ : the median $\mathrm{NO}_{2}{ }^{-} / \mathrm{NO}_{3}{ }^{-}$ levels across quartiles of $\mathrm{PM}_{10}$ concentration were 1.9 $\mu \mathrm{mol} / \mathrm{mg}$ (Q1- Q3: 0.9, 3.6), $2.0 \mu \mathrm{mol} / \mathrm{mg}$ (Q1-Q3: 0.92, 4.1), $2.5 \mu \mathrm{mol} / \mathrm{mg}$ (Q1-Q3: $1.2,5.1$ ) and $1.4 \mu \mathrm{mol} / \mathrm{mg}$ (Q1-Q3: 0.7 , 2.9). Similar results were observed among non-asthmatics only (results not shown). Including storage time as a covariate in the regression model did not change the associations between smoking and leafy vegetable consumption with $\mathrm{NO}_{2}{ }^{-} / \mathrm{NO}_{3}{ }^{-}$level in EBC (results not shown).

\section{DISCUSSION}

The present study focused for the first time on the associations between four environmental exposures and total $\mathrm{NO}_{2}{ }^{-} / \mathrm{NO}_{3}{ }^{-}$ levels measured both in plasma and in EBC among nearly 1000 adults. Total plasma $\mathrm{NO}_{2}{ }^{-} / \mathrm{NO}_{3}{ }^{-}$levels were higher in menopausal women, increased with leafy vegetable consumption, and decreased in current smokers. A similar association with smoking was observed in EBC. Lower levels of total EBC $\mathrm{NO}_{2}{ }^{-} / \mathrm{NO}_{3}{ }^{-}$were found in association with increasing annual ambient concentration concentrations of $\mathrm{O}_{3}$. The major assets of the study are the sample size, the standardization of the sample collection, the measurements of relevant biological markers and the availability of four different environmental exposures. Measurements of total $\mathrm{NO}_{2}{ }^{-} / \mathrm{NO}_{3}{ }^{-}$ levels both in plasma and EBC were consistent with the standard reference values proposed by Ghasemi et al [30] for plasma, and with levels measured in several clinical studies for EBC [31]. The major limitations are the cross-sectional nature of the data and the retrospective ascertainment of exposure to environmental sources. Estimation of ambient $\mathrm{NO}_{2}$ concentrations was not very precise because the air pollution model used $(4 \mathrm{~km} \times 4 \mathrm{~km})$ was more appropriate for secondary or long-range pollutants with a relatively homogeneous distribution over longer distances, such as $\mathrm{O}_{3}$ and $\mathrm{PM}_{10}$.

In our study, plasma levels of $\mathrm{NO}_{2}{ }^{-} / \mathrm{NO}_{3}{ }^{-}$increased with age only in women and were higher in menopausal women. Similar findings were observed by Ghasemi et al [32], where the highest upper $\mathrm{NO}_{2}{ }^{-} / \mathrm{NO}_{3}{ }^{-}$limits were seen in subjects older than 50 years $(\mathrm{N}=1983)$.

It was hard to disentangle the effect of age and menopause on plasma $\mathrm{NO}_{2}{ }^{-} / \mathrm{NO}_{3}{ }^{-}$levels. Watanabe et al [33] observed that $\mathrm{NO}_{2}{ }^{-} / \mathrm{NO}_{3}{ }^{-}$levels increased with age in 118 women, but did not in 145 men. This result and ours may suggest a role of menopause on plasma $\mathrm{NO}_{2}{ }^{-} / \mathrm{NO}_{3}{ }^{-}$levels. Higashino et al [34] recently suggested that increasing plasma $\mathrm{NO}_{2}{ }^{-} / \mathrm{NO}_{3}{ }^{-}$levels in menopausal women may be due to estrogen deficiencyinduced iNOs expression in the vessels of older women, iNOs being one of the three NO synthase isoforms that endogenously produce NO [35]. Unlike plasma, age, menopausal status and sex seem to have no effect on $\mathrm{NO}_{2}{ }^{-} / \mathrm{NO}_{3}{ }^{-}$levels in EBC. Similarly, Cruz et al. [36] showed that neither nitrite nor nitrate measured in EBC varied with age in 75 healthy non-smokers aged 18 to 80 years, and Chladkova et al. [37] found no effect of age on nitrite and nitrate concentrations in EBC of 50 healthy subjects aged 659 years. Overall, these results suggest specificities of $\mathrm{NO}$ metabolism in EBC and in plasma.

We found that plasma $\mathrm{NO}_{2}^{-} / \mathrm{NO}_{3}{ }^{-}$levels increased with consumption of leafy vegetables but not of cured meat. Our results regarding leafy vegetables are in agreement with the findings of Lundberg and Govoni [38], who found that inorganic nitrate ingestion led to increased levels of $\mathrm{NO}_{2}{ }^{-}$and $\mathrm{NO}_{3}{ }^{-}$in the plasma of 9 healthy volunteers. More recently, Zand et al [39] showed that $\mathrm{NO}$ dietary supplement twice daily for 30 days increased both levels of $\mathrm{NO}_{2}^{-}$and $\mathrm{NO}_{3}^{-}$in the plasma in 23 patients as compared to 7 controls. The potential beneficial effect of dietary $\mathrm{NO}_{3}^{-}$on health is currently a topic of increasing 
interest $[40 ; 41]$. Using a randomized crossover study design, Kapil et al [42] showed that nitrate supplementation or vegetable intake (beetroot juice) in the previous 24 hours were associated with a dose-dependent increase in plasma $\mathrm{NO}_{2}{ }_{2}^{-}$ and $\mathrm{NO}_{3}^{-}$levels, with a consequent decrease in blood pressure in 30 healthy volunteers. Previously, inhibition of platelet aggregation and restored endothelial function were observed 3 hours after ingestion of beetroot juice in 14 healthy volunteers [43]. Overall, these results suggest that leafy vegetable consumption may exert its beneficial effect on health partly through an increase in plasma $\mathrm{NO}_{2}{ }^{-}$and $\mathrm{NO}_{3}{ }^{-}$levels.

In our study, we found that exposure to tobacco smoke was negatively associated with both plasma and $\mathrm{EBC} \mathrm{NO}_{2}{ }^{-} / \mathrm{NO}_{3}{ }^{-}$ levels. These findings are not in agreement with those of Ghasemi et al [15], who reported an increase in serum $\mathrm{NO}_{2}{ }^{-} / \mathrm{NO}_{3}{ }^{-}$levels in current smokers compared with non- or passive smokers in 333 healthy men. Plasma $\mathrm{NO}_{2}{ }^{-} / \mathrm{NO}_{3}{ }^{-}$ levels of 35 cigarette smokers were increased when compared to 35 controls in the paper by Padmavathi et al. [44]. A transient increase in $\mathrm{NO}_{2}^{-} / \mathrm{NO}_{3}{ }^{-}$levels was also shown by Balint [7] in EBC after experimental exposure to tobacco smoke. The different covariates taken into account in the multivariate model by Ghasemi et al (body mass index, total cholesterol, triglycerides, 2-h post load glucose, creatinine, systolic blood pressure) may explain the difference with our results. Furthermore, besides differences in the techniques used for EBC collection or analyses, differences in the definition of smokers and in the number of cigarette smoked per day may explain discrepancies between studies.

In the EGEA study, we previously found that both active and passive smoking decreased FeNO levels [22], as observed in other epidemiological studies [10]. The negative association between smoking and FeNO levels is explained by the high concentration of $\mathrm{NO}$ in tobacco smoke, which exerts negative feedback on its synthesis [45], and by the downregulation of NO synthase activity in respiratory tract cells [46]. Since $\mathrm{NO}_{2}{ }^{-} / \mathrm{NO}_{3}{ }^{-}$and $\mathrm{FeNO}$ are both biological markers of the same pathway, their negative association with smoking may be explained by the same mechanism. The lower plasma and EBC $\mathrm{NO}_{2}{ }^{-} / \mathrm{NO}_{3}{ }^{-}$levels observed in smokers compared to exor non-smokers and the negative association with daily tobacco consumption observed in plasma also suggest that the same negative feedback may partly be involved in both compartments. We observed for the first time a decrease in EBC $\mathrm{NO}_{2}{ }^{-} / \mathrm{NO}_{3}{ }^{-}$levels according to exposure to $\mathrm{O}_{3}$, categorized as above/below annual mean. This decrease was of similar magnitude to the decrease in $\mathrm{NO}_{2}{ }^{-} / \mathrm{NO}_{3}{ }^{-}$level observed in current versus non- and ex-smokers. Epidemiological observations on the associations of ambient air pollution with biomarkers in body fluids are still lacking. To our knowledge, there is no other epidemiological study on the effects of air pollution on $\mathrm{NO}_{2}{ }^{-} / \mathrm{NO}_{3}{ }^{-}$levels. We did not evidence any associations of ambient exposure to $\mathrm{PM}_{10}$ or $\mathrm{NO}_{2}$ with plasma or $\mathrm{EBC} \mathrm{NO}_{2}{ }^{-} / \mathrm{NO}_{3}{ }^{-}$levels, a finding partly at variance with the results of Shah et al [47] who reported a significant decrease in plasma $\mathrm{NO}_{3}$ levels after acute controlled exposure to ultrafine carbon particles in 16 subjects. We could have expected an association of ambient $\mathrm{NO}_{2}$ concentrations on $\mathrm{NO}_{2}{ }^{-} / \mathrm{NO}_{3}{ }^{-}$levels in body fluids, but it should be noted that the available estimate of ambient $\mathrm{NO}_{2}$ concentrations in our study was not very precise. Of interest in our study was the availability of EBC measures to evaluate the potential effects of inhaled exposures. Consistent with our findings, a decrease of FeNO levels in exhaled air, a related marker of the same NO pathway, was observed by Liu et al. after acute exposure to $\mathrm{O}_{3}$ in 182 asthmatic children [48]. The mechanism(s) by which $\mathrm{O}_{3}$ may influence biological markers in the NO pathway might be an inhibition of NOS activity [49] or through oxidative stress.

Further research is needed on the chronic effects of ambient air pollution on body fluids, particularly EBC, to better understand the associations with respiratory and cardiovascular effects. Overall, the specificities of NO metabolism in plasma and EBC may partly explain our results. They are consistent with the hypotheses of Villanueva et al. [50], for whom such compartmentalized production of $\mathrm{NO}$ better explains its different functions and roles in pathophysiology.

\section{CONCLUSION}

In conclusion, we report for the first time that environmental and behavioral risk factors may modify $\mathrm{NO}_{2}{ }^{-} / \mathrm{NO}_{3}{ }^{-}$levels. Our results suggest specificities of NO metabolism in EBC and in plasma and highlight the importance of studying the same biological marker in different compartments. These findings could have implications for several diseases for which oxidative and nitrosative stresses are involved in their physiopathological pathways. Further studies are needed especially in the general population to better understand which environmental and social factors are related to which biomarkers. This would provide insights into the underlying biological mechanisms of diseases.

\section{ACKNOWLEDGMENTS}

The authors thank all those who participated in the study and in the various aspects of the examinations and all those who supervised the study in all centers. The authors are grateful to the three $\mathrm{CIC}$-Inserm units of Necker, Grenoble and Marseille which supported the study and where subjects were examined. They are also grateful to the three biobanks in Lille (CICInserm), Evry (Centre National de Genotypage) and Annemasse (Etablissement francais du sang) where biological samples are stored. They are indebted to all the individuals who participated, without whom the study would not have been possible.

EGEA cooperative group Coordination: F Kauffmann; V Siroux (epidemiology); F Demenais (genetics); I Pin (clinical aspects); R Nadif (biology). Respiratory epidemiology: Inserm U 700, Paris M Korobaeff (Egea1), F Neukirch (Egea1); Inserm U 707, Paris: I Annesi-Maesano; Inserm CESP/U 1018, Villejuif: F Kauffmann, N Le Moual, R Nadif, MP Oryszczyn; Inserm U 823, Grenoble: V Siroux. Genetics: Inserm U 393, Paris : J Feingold ; Inserm U 946, Paris : E Bouzigon , F Demenais, MH Dizier; CNG, Evry : I Gut (now CNAG), M Lathrop (now CEPH/Mc Gill). Clinical centers: Grenoble: I Pin, C Pison; Lyon: D Ecochard (Egea1), F Gormand, Y Pacheco; Marseille: D Charpin (Egea1), D Vervloet; Montpellier: J Bousquet; Paris Cochin: A Lockhart (Egea1), R Matran (now in Lille); Paris Necker: E Paty, P Scheinmann; Paris-Trousseau: A Grimfeld, J Just. Data and quality management: Inserm exU155 (Egea1): J Hochez; Inserm CESP/U 1018, Villejuif: N Le Moual, Inserm ex-U780: C Ravault; Inserm ex-U794: N Chateigner; Grenoble: J Ferran.

\section{FUNDING}

This research is funded in part by PHRC-Paris, PHRCGrenoble, ANR 05-SEST-020-02/05-9-97, ANR-06-CEBS, ANR-CES-2009, Region Nord Pas-de-Calais, Merck Sharp \& Dohme (MSD), the GA2LEN project, Global Allergy and Asthma European Network.

\section{References}

[1] B.r.S. Rocha, B. Gago, C. Pereira, R.M. Barbosa, S. Bartesaghi, J.O. Lundberg, R. Radi, and J.Â. Laranjinha, Dietary Nitrite in Nitric Oxide Biology: A Redox Interplay with Implications for Pathophysiology and Therapeutics. Curr Drug Targets (2011) -

[2] J.O. Lundberg, M.T. Gladwin, A. Ahluwalia, N. Benjamin, N.S. Bryan, A. Butler, P. Cabrales, A. Fago, M. Feelisch, P.C. Ford, B.A. Freeman, M. Frenneaux, J. Friedman, M. Kelm, C.G. Kevil, D.B. Kim-Shapiro, A.V. Kozlov, J.J.R. Lancaster, D.J. Lefer, K. McColl, K. McCurry, R.P. Patel, J. Petersson, T. Rassaf, V.P. Reutov, G.B. Richter-Addo, A. Schechter, S. Shiva, K. Tsuchiya, E.E. van Faassen, A.J. Webb, B.S. Zuckerbraun, J.L. Zweier, and E. Weitzberg, Nitrate and nitrite in biology, nutrition and therapeutics. Nat Chem Biol 5 (2009) 865-9.

[3] F.L.M. Ricciardolo, A.D. Stefano, F. Sabatini, and G. Folkerts, Reactive nitrogen species in the respiratory tract. Eur J Pharmacol 533 (2006) 240-252.

[4] J.O. Lundberg, and E. Weitzberg, Biology of nitrogen oxides in the gastrointestinal tract. Gut (2012). 
[5] C. Menard, F. Heraud, J.L. Volatier, and J.C. Leblanc, Assessment of dietary exposure of nitrate and nitrite in France. Food Addit Contam Part A Chem Anal Control Expo Risk Assess 25 (2008) 971-988.

[6] W.A. Pryor, and K. Stone, Oxidants in cigarette smoke. Radicals, hydrogen peroxide, peroxynitrate, and peroxynitrite. Ann N Y Acad Sci 686 (1993) 12-27; discussion 27-8.

[7] B. Balint, L.E. Donnelly, T. Hanazawa, S.A. Kharitonov, and P.J. Barnes, Increased nitric oxide metabolites in exhaled breath condensate after exposure to tobacco smoke. Thorax 56 (2001) 456.

[8] J.A. Bernstein, N. Alexis, C. Barnes, I.L. Bernstein, J.A. Bernstein, A. Nel, D. Peden, D. Diaz-Sanchez, S.M. Tarlo, and P.B. Williams, Health effects of air pollution. J Allergy Clin Immunol 114 (2004) 1116-23.

[9] J.G. Martin, H.R. Campbell, H. lijima, D. Gautrin, J.L. Malo, D.H. Eidelman, Q. Hamid, and K. Maghni, Chlorineinduced injury to the airways in mice. Am J Respir Crit Care Med 168 (2003) 568-74.

[10] S. Karrasch, K. Ernst, J. Behr, J. Heinrich, R.M. Huber, D. Nowak, H.E. Wichmann, S.E. Baumeister, C. Meisinger, K.H. Ladwig, R. Holle, R.A. Jorres, and H. Schulz, Exhaled nitric oxide and influencing factors in a random population sample. Respir Med 105 (2011) 713-8.

[11] K. Berhane, Y. Zhang, W.S. Linn, E.B. Rappaport, T.M. Bastain, M.T. Salam, T. Islam, F. Lurmann, and F.D. Gilliland, The effect of ambient air pollution on exhaled nitric oxide in the Children's Health Study. Eur Respir J 37 (2000) 1029-1036.

[12] M.S. Perzanowski, A. Divjan, R.B. Mellins, S.M. Canfield, M.J. Rosa, G.L. Chew, A. Rundle, I.F. Goldstein, and J.S. Jacobson, Exhaled NO among inner-city children in New York City. J Asthma 47 (2010) 1015-1021.

[13] A.K.M. Fell, N. H, M. Skogstad, K.-C. Nordby, W. Eduard, M.V. Svendsen, R. Ovstebø, A.M.S. Trøseid, and J. Kongerud, A cross-shift study of lung function, exhaled nitric oxide and inflammatory markers in blood in Norwegian cement production workers. Occup Environ Med (2011) -.

[14] M. Gube, J. Ebel, P. Brand, T. GÃđen, K. Holzinger, U. Reisgen, and T. Kraus, Biological effect markers in exhaled breath condensate and biomonitoring in welders: impact of smoking and protection equipment. Int Arch Occup Environ Health 83 (2010) 803-11.

[15] A. Ghasemi, L. Syedmoradi, A.A. Momenan, S. Zahediasl, and F. Azizi, The influence of cigarette and qalyan (hookah) smoking on serum nitric oxide metabolite concentration. Scand J Clin Lab Invest 70 (2010) 116-121.

[16] J.O. Lundberg, and E. Weitzberg, NO-synthase independent NO generation in mammals. Biochem Biophys Res Commun 396 (2010) 39-45.

[17] J. Hunt, Exhaled breath condensate: an evolving tool for noninvasive evaluation of lung disease. J Allergy Clin Immunol 110 (2002) 28-34.

[18] J. Hunt, Exhaled breath condensate: an overview. Immunol Allergy Clin North Am 27 (2007) 587-96; v.

[19] A.M. Fitzpatrick, L.A. Brown, F. Holguin, and W.G. Teague, Levels of nitric oxide oxidation products are increased in the epithelial lining fluid of children with persistent asthma. J Allergy Clin Immunol 124 (2009) 9906 e1-9.

[20] F. Kauffmann, and M.H. Dizier, EGEA (Epidemiological study on the Genetics and Environment of Asthma, bronchial hyperresponsiveness and atopy)--design issues. EGEA Co-operative Group. Clin Exp Allergy 25 Suppl 2 (1995) 19-22.

[21] F. Kauffmann, M.H. Dizier, I. Pin, E. Paty, F. Gormand, D. Vervloet, J. Bousquet, F. Neukirch, I. Annesi, M.P. Oryszczyn, M. Lathrop, F. Demenais, A. Lockhart, and J. Feingold, Epidemiological study of the genetics and environment of asthma, bronchial hyperresponsiveness, and atopy: phenotype issues. Am J Respir Crit Care Med 156 (1997) S123-S129.

[22] R. Nadif, R. Matran, J. Maccario, M. Bechet, N. Le Moual, P. Scheinmann, J. Bousquet, F. Kauffmann, and I. Pin, Passive and active smoking and exhaled nitric oxide levels according to asthma and atopy in adults. Ann Allergy Asthma Immunol 104 (2010) 385-93.

[23] H. Moshage, B. Kok, J.R. Huizenga, and P.L. Jansen, Nitrite and nitrate determinations in plasma: a critical evaluation. Clin Chem 41 (1995) 892-6.

[24] P.K. Smith, Measurement of protein using bicinchoninic acid, 1989, pp. -

[25] R. Nadif, B. Decoster, H. Huyvaert, G. Briand, N. Le Moual, I. Pin, V. Siroux, R. Varraso, F. Kauffmann, F. Zerimech, and others, Total Nitrate/Nitrite Levels In Plasma And Exhaled Breath Condensate: Associations With Age And Smoking According To Asthma Among 1159 Adults From The EGEA Study. Am J Respir Crit Care Med 181 (2010) -A3109.

[26] C. Bonifacj, M. Gerber, J. Scali, and J.P. Daures, Comparison of dietary assessment methods in a southern French population: use of weighed records, estimated-diet records and a food-frequency questionnaire. Eur J Clin Nutr 51 (1997) 217-231.

[27] E. Rage, V. Siroux, N. KÃ¹/4nzli, I. Pin, F. Kauffmann, E.S. on the Genetics, and E. of Asthma, Air pollution and asthma severity in adults. Occup Environ Med 66 (2009) 182-188.

[28] C. Donnay, M.A. Denis, R. Magis, J. Fevotte, N. Massin, O. Dumas, I. Pin, D. Choudat, F. Kauffmann, and N.L. Moual, Under-estimation of self-reported occupational exposure by questionnaire in hospital workers. Occup Environ Med 68 (2011) 611-617

[29] J.P. Zock, E. Plana, D. Jarvis, J.M. Anto, H. Kromhout, S.M. Kennedy, N. Kunzli, S. Villani, M. Olivieri, K. Toren, K. Radon, J. Sunyer, A. Dahlman-Hoglund, D. Norback, and M. Kogevinas, The use of household cleaning sprays and adult asthma: an international longitudinal study. Am J Respir Crit Care Med 176 (2007) 735-41.

[30] A. Ghasemi, S. Zahediasl, and F. Azizi, Reference values for serum nitric oxide metabolites in an adult population. Clin Biochem 43 (2010) 89-94.

[31] J. Liu, A. Sandrini, M.C. Thurston, D.H. Yates, and P.S. Thomas, Nitric oxide and exhaled breath nitrite/nitrates in chronic obstructive pulmonary disease patients. Respiration 74 (2007) 617-623.

[32] A. Ghasemi, S.Z. Asl, Y. Mehrabi, N. Saadat, and F. Azizi, Serum nitric oxide metabolite levels in a general healthy population: relation to sex and age. Life Sci 83 (2008) 326331.

[33] T. Watanabe, M. Akishita, K. Toba, K. Kozaki, M. Eto, N. Sugimoto, T. Kiuchi, M. Hashimoto, W. Shirakawa, and Y. Ouchi, Influence of sex and age on serum nitrite/nitrate concentration in healthy subjects. Clin Chim Acta 301 (2000) 169-79

[34] H. Higashino, H. Miya, H. Mukai, and Y. Miya, Serum nitric oxide metabolite $(\mathrm{NO}(\mathrm{x}))$ levels in hypertensive patients at rest: a comparison of age, gender, blood pressure and complications using normotensive controls. Clin Exp Pharmacol Physiol 34 (2007) 725-731.

[35] W.K. Alderton, C.E. Cooper, and R.G. Knowles, Nitric oxide synthases: structure, function and inhibition. Biochem J 357 (2001) 593-615.

[36] M.J. Cruz, S. Sanchez-Vidaurre, P.V. Romero, F. Morell, and $\mathrm{X}$. Munoz, Impact of age on $\mathrm{pH}$, 8-isoprostane, and nitrogen oxides in exhaled breath condensate. Chest 135 (2009) 462-7.

[37] J. Chladkova, I. Krcmova, J. Chladek, P. Cap, S. Micuda and $Y$. Hanzalkova, Validation of nitrite and nitrate measurements in exhaled breath condensate. Respiration 73 (2006) 173-9

[38] J.O. Lundberg, and M. Govoni, Inorganic nitrate is a possible source for systemic generation of nitric oxide. Free Radic Biol Med 37 (2004) 395-400.

[39] J. Zand, F. Lanza, H.K. Garg, and N.S. Bryan, All-natural nitrite and nitrate containing dietary supplement promotes nitric oxide production and reduces triglycerides in humans. Nutr Res 31 (2011) 262-9.

[40] J.J. Sindelar, and A.L. Milkowski, Human safety controversies surrounding nitrate and nitrite in the diet. Nitric Oxide (2012)

[41] F.J. Larsen, T.A. Schiffer, S. Borniquel, K. Sahlin, B.r. Ekblom, J.O. Lundberg, and E. Weitzberg, Dietary 
inorganic nitrate improves mitochondrial efficiency in humans. Cell Metab 13 (2011) 149-159.

[42] V. Kapil, A.B. Milsom, M. Okorie, S. Maleki-Toyserkani, F. Akram, F. Rehman, S. Arghandawi, V. Pearl, N. Benjamin, S. Loukogeorgakis, R. Macallister, A.J. Hobbs, A.J. Webb, and A. Ahluwalia, Inorganic nitrate supplementation lowers blood pressure in humans: role for nitrite-derived NO. Hypertension 56 (2010) 274-81.

[43] A.J. Webb, N. Patel, S. Loukogeorgakis, M. Okorie, Z. Aboud, S. Misra, R. Rashid, P. Miall, J. Deanfield, N. Benjamin, R. MacAllister, A.J. Hobbs, and A. Ahluwalia, Acute blood pressure lowering, vasoprotective, and antiplatelet properties of dietary nitrate via bioconversion to nitrite. Hypertension 51 (2008) 784-90

[44] P. Padmavathi, V.D. Reddy, G. Kavitha, M. Paramahamsa, and N. Varadacharyulu, Chronic cigarette smoking alters erythrocyte membrane lipid composition and properties in male human volunteers. Nitric Oxide 23 (2010) 181-6.

[45] G.M. Buga, J.M. Griscavage, N.E. Rogers, and L.J. Ignarro, Negative feedback regulation of endothelial cell function by nitric oxide. Circ Res 73 (1993) 808-12.
[46] S.A. Kharitonov, R.A. Robbins, D. Yates, V. Keatings, and P.J. Barnes, Acute and chronic effects of cigarette smoking on exhaled nitric oxide. Am J Respir Crit Care Med 152 (1995) 609-12.

[47] A.P. Shah, A.P. Pietropaoli, L.M. Frasier, D.M. Speers, D.C. Chalupa, J.M. Delehanty, L.-S. Huang, M.J. Utell, and M.W. Frampton, Effect of inhaled carbon ultrafine particles on reactive hyperemia in healthy human subjects. Environ Health Perspect 116 (2008) 375-380.

[48] L. Liu, R. Poon, L. Chen, A.-M. Frescura, P. Montuschi, G. Ciabattoni, A. Wheeler, and R. Dales, Acute effects of air pollution on pulmonary function, airway inflammation, and oxidative stress in asthmatic children. Environ Health Perspect 117 (2009) 668-674.

[49] H. Inoue, H. Aizawa, H. Nakano, K. Matsumoto, K. Kuwano, J.A. Nadel, and N. Hara, Nitric oxide synthase inhibitors attenuate ozone-induced airway inflammation in guinea pigs. Possible role of interleukin-8. Am J Respir Crit Care Med 161 (2000) 249-256.

[50] C. Villanueva, and C. Giulivi, Subcellular and cellular locations of nitric oxide synthase isoforms as determinants of health and disease. Free Radic Biol Med 49 (2010) 307316. 


\begin{tabular}{|c|c|c|c|c|c|c|c|}
\hline \multirow[b]{2}{*}{ Characteristics } & \multirow{2}{*}{$\begin{array}{l}\text { All subjects } \\
(\mathrm{N}=949)\end{array}$} & \multicolumn{3}{|c|}{ Stratified by asthma } & \multicolumn{3}{|c|}{ Stratified by sex } \\
\hline & & $\begin{array}{l}\text { Non } \\
\text { Asthmatics } \\
(\mathrm{N}=524)\end{array}$ & $\begin{array}{l}\text { Asthmatics } \\
(\mathrm{N}=425)\end{array}$ & $\begin{array}{l}\text { P- } \\
\text { value }^{a}\end{array}$ & $\begin{array}{l}\text { Males } \\
(\mathrm{N}=457)\end{array}$ & $\begin{array}{l}\text { Females } \\
(\mathrm{N}=492)\end{array}$ & $\begin{array}{l}\text { P- } \\
\text { value }^{a}\end{array}$ \\
\hline Sex (men), \% & 48.2 & 43.9 & 53.4 & 0.01 & & & \\
\hline \multicolumn{8}{|l|}{ Age groups (years), \% } \\
\hline $15-24$ & 21.2 & 12.8 & 31.5 & $<.001$ & 23.9 & 18.7 & \\
\hline $25-34$ & 18.5 & 16.6 & 20.9 & & 17.9 & 19.1 & \\
\hline $35-44$ & 11.5 & 13.4 & 9.2 & & 10.1 & 12.8 & \\
\hline $45-54$ & 21.2 & 24.8 & 16.7 & & 19.5 & 22.8 & \\
\hline$>=55$ & 27.6 & 32.4 & 21.6 & & 28.7 & 26.6 & \\
\hline Menopausal status ${ }^{\mathrm{b}}, \%$ & 36.1 & 41.1 & 28.7 & & - & 36.1 & \\
\hline \multicolumn{8}{|l|}{ Smoking status, $\%$} \\
\hline Non/ex-smokers & 77.6 & 79.7 & 75.1 & 0.99 & 74.8 & 80.2 & 0.06 \\
\hline Current smokers & 22.4 & 20.3 & 24.9 & & 25.2 & 19.8 & \\
\hline \multicolumn{8}{|l|}{$\begin{array}{l}\text { Tobacco, } \\
\text { daily consumption', \% }\end{array}$} \\
\hline$<10 \mathrm{~g} /$ day & 52.6 & 56.3 & 49.1 & 0.43 & 50.9 & 54.6 & 0.70 \\
\hline $10-20 \mathrm{~g} /$ day & 33.0 & 28.2 & 37.7 & & 34.8 & 30.9 & \\
\hline$>20 \mathrm{~g} /$ day & 14.4 & 15.5 & 13.2 & & 13.9 & 43.4 & \\
\hline \multicolumn{8}{|l|}{$\begin{array}{l}\text { Food intake, } \\
\text { Median (Q1-Q3) }\end{array}$} \\
\hline Cured meat (serving/day) & $\begin{array}{l}0.14(0.07 \\
0.21)\end{array}$ & $\begin{array}{l}0.14(0.07 \\
0.21)\end{array}$ & $\begin{array}{l}0.14(0.07 \\
0.28)\end{array}$ & $<.001$ & $\begin{array}{l}0.2 \\
(0.1 \\
0.3)\end{array}$ & $\begin{array}{l}0.1(0 \\
0.2)\end{array}$ & $<.001$ \\
\hline $\begin{array}{l}\text { Leafy vegetables } \\
\text { (serving/day) }\end{array}$ & $0.8(0.4,1.1)$ & $\begin{array}{l}0.9(0.5 \\
1.1)\end{array}$ & $\begin{array}{l}0.6(0.4 \\
1.1)\end{array}$ & 0.83 & $\begin{array}{l}3.1 \\
(2.0 \\
4.4)\end{array}$ & $\begin{array}{l}3.8(2.6 \\
5.2)\end{array}$ & $<.001$ \\
\hline $\begin{array}{l}\text { Exposure to chlorine } \\
\text { products, } \%\end{array}$ & 29.2 & 30.0 & 28.1 & 0.43 & $\begin{array}{l}0.6 \\
(0.4 \\
1.1)\end{array}$ & $\begin{array}{l}0.9(0.5 \\
1.2)\end{array}$ & $<.001$ \\
\hline \multicolumn{8}{|l|}{$\begin{array}{l}\text { Air pollutant exposure, } \\
\text { Median (Q1-Q3) }\end{array}$} \\
\hline $\mathrm{NO}_{2}\left(\mu \mathrm{g} / \mathrm{m}^{3}\right)$ & $\begin{array}{l}34.5(26.3 \\
38.0)\end{array}$ & $\begin{array}{l}35.0(27.3 \\
39.9)\end{array}$ & $\begin{array}{l}32.3(24.6 \\
38.0)\end{array}$ & 0.001 & $\begin{array}{l}34.4 \\
(26.5 \\
38.0)\end{array}$ & $\begin{array}{l}34.6 \\
(26.3 \\
39.9)\end{array}$ & 0.55 \\
\hline $\mathrm{O}_{3}\left(\mu \mathrm{g} / \mathrm{m}^{3}\right)$ & $\begin{array}{l}44.1(41.0 \\
50.3)\end{array}$ & $\begin{array}{l}43.6(40.7 \\
50.0)\end{array}$ & $\begin{array}{l}45.1(41.0 \\
51.3)\end{array}$ & 0.04 & $\begin{array}{l}43.9 \\
(41.3 \\
49.9)\end{array}$ & $\begin{array}{l}44.1 \\
(40.7 \\
51.6)\end{array}$ & 0.46 \\
\hline $\mathrm{PM}_{10}\left(\mu \mathrm{g} / \mathrm{m}^{3}\right)$ & $\begin{array}{l}20.6(18.8, \\
21.6)\end{array}$ & $\begin{array}{l}20.8(19.5 \\
21.7)\end{array}$ & $\begin{array}{l}20.5(18.4, \\
21.4)\end{array}$ & 0.18 & $\begin{array}{l}20.6 \\
(18.6 \\
21.6)\end{array}$ & $\begin{array}{l}20.6 \\
(19.0 \\
21.4)\end{array}$ & 0.88 \\
\hline \multicolumn{8}{|c|}{ Nitrite/nitrate concentration, Median (Q1-Q3) } \\
\hline In plasma $(\mu \mathrm{M})$ & $\begin{array}{r}36.3(25.7 \\
51.1)\end{array}$ & $\begin{array}{r}35.5(24.2 \\
51.2)\end{array}$ & $\begin{array}{l}37.0(26.8, \\
51.1)\end{array}$ & 0.42 & $\begin{array}{l}36.5 \\
(25.9 \\
50.4)\end{array}$ & $\begin{array}{l}36.0 \\
(25.4 \\
52.3)\end{array}$ & 0.75 \\
\hline In EBC $(\mu \mathrm{mol} / \mu \mathrm{g})$ & $2.0(0.9,3.9)$ & $\begin{array}{r}2.0(0.9 \\
3.9)\end{array}$ & $\begin{array}{l}2.0(0.9 \\
4.0)\end{array}$ & 0.54 & $\begin{array}{l}1.9 \\
(0.8 \\
3.6) \\
\end{array}$ & $\begin{array}{l}2.1(1.0 \\
4.1)\end{array}$ & 0.08 \\
\hline
\end{tabular}


Table 2. Association between Plasma Total $\mathrm{NO}_{2}{ }^{-} / \mathrm{NO}_{3}{ }^{-}$Level and Environmental Exposures. EGEA Study, France, Second Survey, 2003-2007

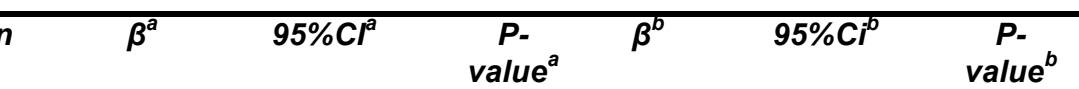

\begin{tabular}{|c|c|c|c|c|c|c|c|}
\hline Age (years, continuous) & 949 & 0.002 & $0.001,0.003$ & 0.001 & & & \\
\hline Pre-menopausal women, vs. men & $308 / 457$ & -0.03 & $-0.06,0.002$ & 0.07 & & & \\
\hline Post-menopausal women, vs. men & $174 / 457$ & 0.05 & $0.007,0.09$ & 0.02 & & & \\
\hline $\begin{array}{l}\text { Current smokers, vs. non/ex- } \\
\text { smokers }\end{array}$ & $212 / 735$ & -0.08 & $-0.12,-0.05$ & $<0.001$ & -0.07 & $-0.10,-0.03$ & $<0.001$ \\
\hline $\begin{array}{l}\text { Tobacco daily consumption }{ }^{c},>=10 \\
\text { g/day }\end{array}$ & $99 / 110$ & -0.07 & $-0.13,-0.02$ & 0.01 & -0.07 & $-0.13,-0.02$ & 0.004 \\
\hline Cured meat (serving/day) ${ }^{d}$ & 807 & -0.03 & $-0.06,0.01$ & 0.11 & -0.03 & $-0.06,0.01$ & 0.17 \\
\hline Leafy vegetables (serving/day) $^{d}$ & 807 & 0.04 & $0.01,0.07$ & 0.02 & 0.03 & $-0.003,0.07$ & 0.07 \\
\hline Exposure to chlorine products & $275 / 668$ & -0.01 & $-0.04,0.03$ & 0.73 & -0.02 & $-0.06,0.02$ & 0.28 \\
\hline $\mathrm{NO}_{2}\left(\mu \mathrm{g} / \mathrm{m}^{3}\right)^{\mathrm{d}}$ & 899 & -0.01 & $-0.04,0.03$ & 0.68 & -0.004 & $-0.04,0.03$ & 0.85 \\
\hline $\mathrm{O}_{3}\left(\mu \mathrm{g} / \mathrm{m}^{3}\right)^{\mathrm{d}}$ & 926 & -0.001 & $-0.03,0.03$ & 0.96 & -0.01 & $-0.05,0.03$ & 0.60 \\
\hline $\mathrm{PM}_{10}\left(\mu \mathrm{g} / \mathrm{m}^{3}\right)^{\mathrm{d}}$ & 926 & -0.02 & $-0.05,0.02$ & 0.34 & -0.02 & $-0.05,0.02$ & 0.29 \\
\hline
\end{tabular}

Abbreviations: $\mathrm{Cl}$, Confidence Interval; $\mathrm{NO}_{2}$, Nitrogen Dioxide; $\mathrm{O}_{3}$, Ozone; $\mathrm{PM}_{10}$, Particulate Matter;

${ }^{a}$ Estimates for the association between total $\mathrm{NO}_{2}{ }^{-} / \mathrm{NO}_{3}{ }^{-}$and each exposure adjusted for asthma

${ }^{\mathrm{b}}$ Estimates for the association between total $\mathrm{NO}_{2}^{-} / \mathrm{NO}_{3}{ }^{-}$and each exposure adjusted for asthma, age and menopausal status;

${ }^{\mathrm{c}}$ Among current smokers $(\mathrm{N}=209)$

${ }^{\mathrm{d}}$ Continuous exposures included as dichotomous variables (above/below median)

Table 3. Association between EBC Total $\mathrm{NO}_{2}{ }^{-} / \mathrm{NO}_{3}{ }^{-}$Level and Environmental Exposures. EGEA Study, Second Survey, 2003-2007

\begin{tabular}{|c|c|c|c|c|c|c|c|}
\hline Exposure variables & $\bar{n}$ & $\beta^{a}$ & $95 \% \mathrm{Cl}^{a}$ & $\begin{array}{c}P- \\
\text { value }^{a}\end{array}$ & $\beta^{b}$ & $95 \% \mathrm{Ci}^{b}$ & $\begin{array}{c}P- \\
\text { value }^{b}\end{array}$ \\
\hline Age (years, continuous) & 949 & -0.0001 & $-0.002,0.002$ & 1.00 & & & \\
\hline $\begin{array}{l}\text { Pre-menopausal women, vs. } \\
\text { men }\end{array}$ & $308 / 457$ & -0.06 & $-0.01,0.1$ & 0.09 & & & \\
\hline $\begin{array}{l}\text { Post-menopausal women, } \\
\text { vs. men }\end{array}$ & $174 / 457$ & 0.06 & $-0.02,0.14$ & 0.10 & & & \\
\hline $\begin{array}{l}\text { Current smokers, vs. non/ex- } \\
\text { smokers }\end{array}$ & $212 / 735$ & -0.1 & $-0.18,-0.02$ & 0.01 & -0.10 & $-0.17,-0.02$ & 0.01 \\
\hline $\begin{array}{l}\text { Tobacco daily consumption }{ }^{\mathrm{c}} \text {, } \\
>=10 \mathrm{~g} / \text { day }\end{array}$ & $99 / 110$ & 0.009 & $-0.13,0.15$ & 0.90 & 0.01 & $-0.13,0.15$ & 0.91 \\
\hline Cured meat (serving/day) ${ }^{d}$ & 807 & -0.08 & $-0.15,-0.01$ & 0.04 & -0.07 & $-0.14,-0.003$ & 0.04 \\
\hline $\begin{array}{l}\text { Leafy vegetables } \\
\text { (serving/day) }^{d}\end{array}$ & 807 & -0.009 & $-0.08,0.06$ & 0.79 & -0.01 & $-0.08,0.06$ & 0.77 \\
\hline $\begin{array}{l}\text { Exposure to chlorine } \\
\text { products }\end{array}$ & $275 / 668$ & 0.007 & $-0.06,0.08$ & 0.85 & -0.02 & $-0.06,0.02$ & 0.27 \\
\hline $\mathrm{NO}_{2}\left(\mu \mathrm{g} / \mathrm{m}^{3}\right)^{\mathrm{d}}$ & 899 & -0.002 & $-0.07,0.07$ & 0.96 & 0 & $-0.07,0.07$ & 0.98 \\
\hline $\mathrm{O}_{3}\left(\mu \mathrm{g} / \mathrm{m}^{3}\right)^{\mathrm{d}}$ & 926 & -0.14 & $-0.20,-0.07$ & $<0.001$ & -0.14 & $-0.21,-0.07$ & $<0.001$ \\
\hline $\mathrm{PM}_{10}\left(\mu \mathrm{g} / \mathrm{m}^{3}\right)^{\mathrm{d}}$ & 926 & -0.02 & $-0.09,0.05$ & 0.62 & -0.02 & $-0.09,0.05$ & 0.70 \\
\hline
\end{tabular}

Abbreviations: $\mathrm{Cl}$, Confidence Interval; $\mathrm{NO}_{2}$, Nitrogen Dioxide; $\mathrm{O}_{3}$, Ozone; $\mathrm{PM}_{10}$, Particulate Matter;

${ }^{a}$ Estimates for the association between total $\mathrm{NO}_{2}{ }^{-} / \mathrm{NO}_{3}{ }^{-}$and each exposure adjusted for asthma

${ }^{b}$ Estimates for the association between total $\mathrm{NO}_{2}{ }^{-} / \mathrm{NO}_{3}{ }^{-}$and each exposure adjusted for asthma, age and menopausal status;

${ }^{c}$ Among current smokers $(\mathrm{N}=209)$

${ }^{d}$ Continuous exposures included as dichotomous variables (above/below median) 
Table 4. Multivariate Regression Model for the Association between Selected Environmental Exposures and Total $\mathrm{NO}_{2}{ }^{-} / \mathrm{NO}_{3}{ }^{-}$Levels in Plasma and EBC. EGEA Study, Second Survey, 2003-2007

\begin{tabular}{|c|c|c|c|c|c|c|}
\hline \multirow[t]{2}{*}{ Exposure variables } & \multicolumn{3}{|c|}{ Plasma (N=797) } & \multicolumn{3}{|c|}{$E B C(N=625)$} \\
\hline & $\bar{\beta}$ & $95 \% \mathrm{Cl}$ & $\begin{array}{c}\mathrm{P}- \\
\text { value }\end{array}$ & $\beta$ & $95 \% \mathrm{Cl}$ & P-value \\
\hline Asthma & 0.05 & $-0.02,0.05$ & 0.40 & 0.001 & $-0.07,0.07$ & 0.99 \\
\hline Age (years, continuous) & 0.0002 & $-0.001,0.001$ & 0.80 & 0.001 & $-0.003,0.002$ & 0.56 \\
\hline Pre-menopausal women, vs. men & -0.04 & $-0.08,-0.004$ & 0.03 & 0.02 & $-0.07,0.10$ & 0.71 \\
\hline Post-menopausal women, vs. men & 0.02 & $-0.02,0.07$ & 0.33 & 0.04 & $-0.06,0.13$ & 0.45 \\
\hline Current smokers, vs. non/ex-smokers ${ }^{a}$ & -0.08 & $-0.11,-0.04$ & $<0.001$ & -0.08 & $-0.16,-0.001$ & 0.05 \\
\hline $\begin{array}{l}\text { Leafy vegetable consumption } \\
\text { (serving/day), >median }\end{array}$ & 0.04 & $0.001,0.07$ & 0.04 & & & \\
\hline Cured meat (serving/day) ${ }^{\mathrm{b}},>$ median & & & & -0.06 & $-0.14,0.01$ & 0.09 \\
\hline $\mathrm{O}_{3}\left(\mu \mathrm{g} / \mathrm{m}^{3}\right)^{\mathrm{b}},>$ median & & & & -0.10 & $-0.17,-0.03$ & 0.01 \\
\hline
\end{tabular}

Abbreviations: $\mathrm{Cl}$, Confidence Interval; $\mathrm{NO}_{2}$, Nitrogen Dioxide; $\mathrm{O}_{3}$, Ozone; $\mathrm{EBC}$, Exhaled Breath Condensate

a included only in the multivariate model for $\mathrm{NO}_{2}{ }^{-} / \mathrm{NO}_{3}{ }^{-}$in plasma

${ }^{b}$ included only in the multivariate model for $\mathrm{NO}_{2}^{-} / \mathrm{NO}_{3}{ }^{-}$in $\mathrm{EBC}$ 
Figure A.1: Boxplots of total $\mathrm{NO}_{2}{ }^{-} / \mathrm{NO}_{3}{ }^{-}$level in plasma and age in males (a) and females. Whiskers correspond to $1.5^{*}$ interquartile range, the symbol * corresponds to the average $\mathrm{NO}_{2}{ }^{-} / \mathrm{NO}_{3}{ }^{-}$level in the group

(a)

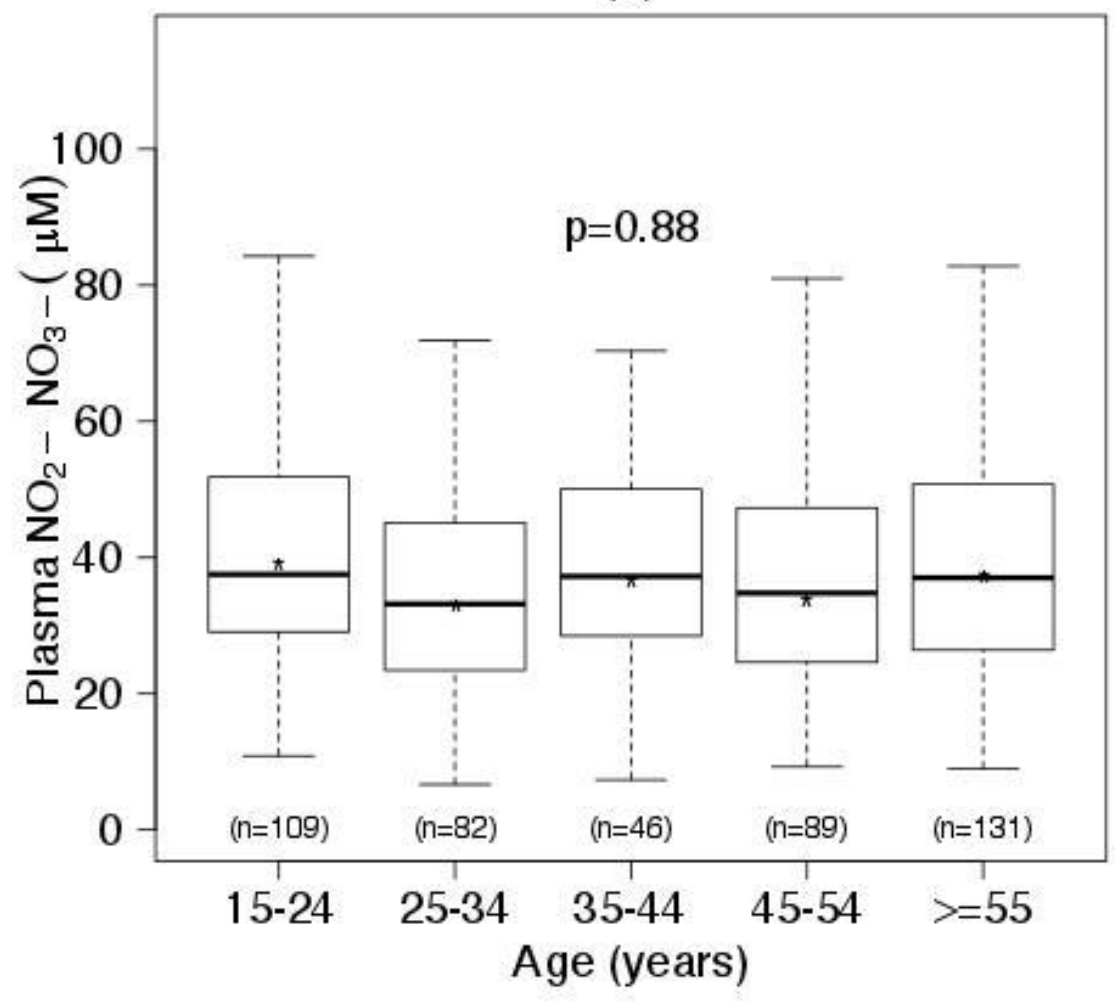

(b)

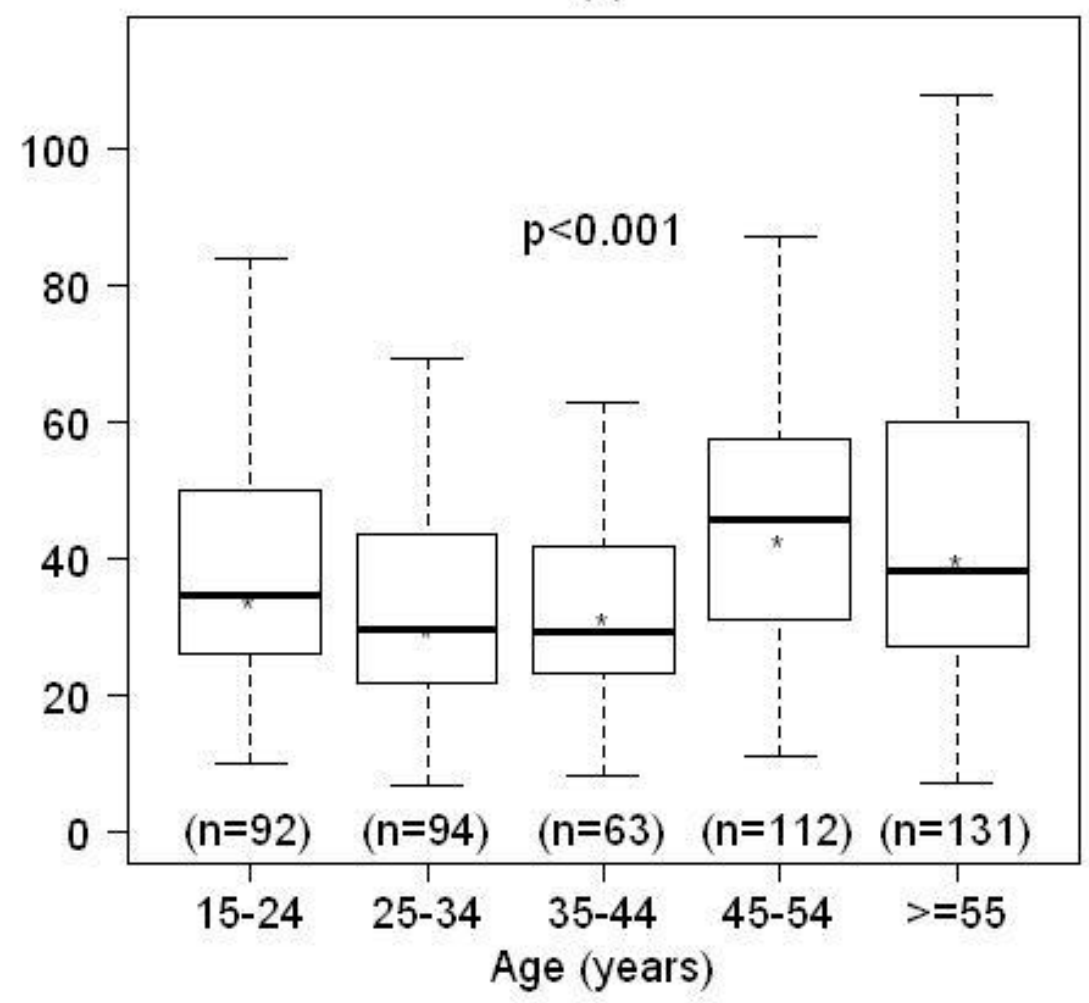


Figure A.2: Boxplots of total $\mathrm{NO}_{2}{ }^{-} / \mathrm{NO}_{3}{ }^{-}$level in plasma and smoking habits (a), tobacco daily consumption among smokers (b), exposure to chlorine products (c), cured meat (d), daily consumption of leafy vegetables (e), $\mathrm{NO}_{2}(\mathrm{f}), \mathrm{O}_{3}(\mathrm{~g})$ and $\mathrm{PM}_{10}(\mathrm{~h})$. Whiskers correspond to $1.5^{*}$ interquartile range, the symbol ${ }^{*}$ corresponds to the average $\mathrm{NO}_{2}{ }^{-} / \mathrm{NO}_{3}{ }^{-}$level in the group
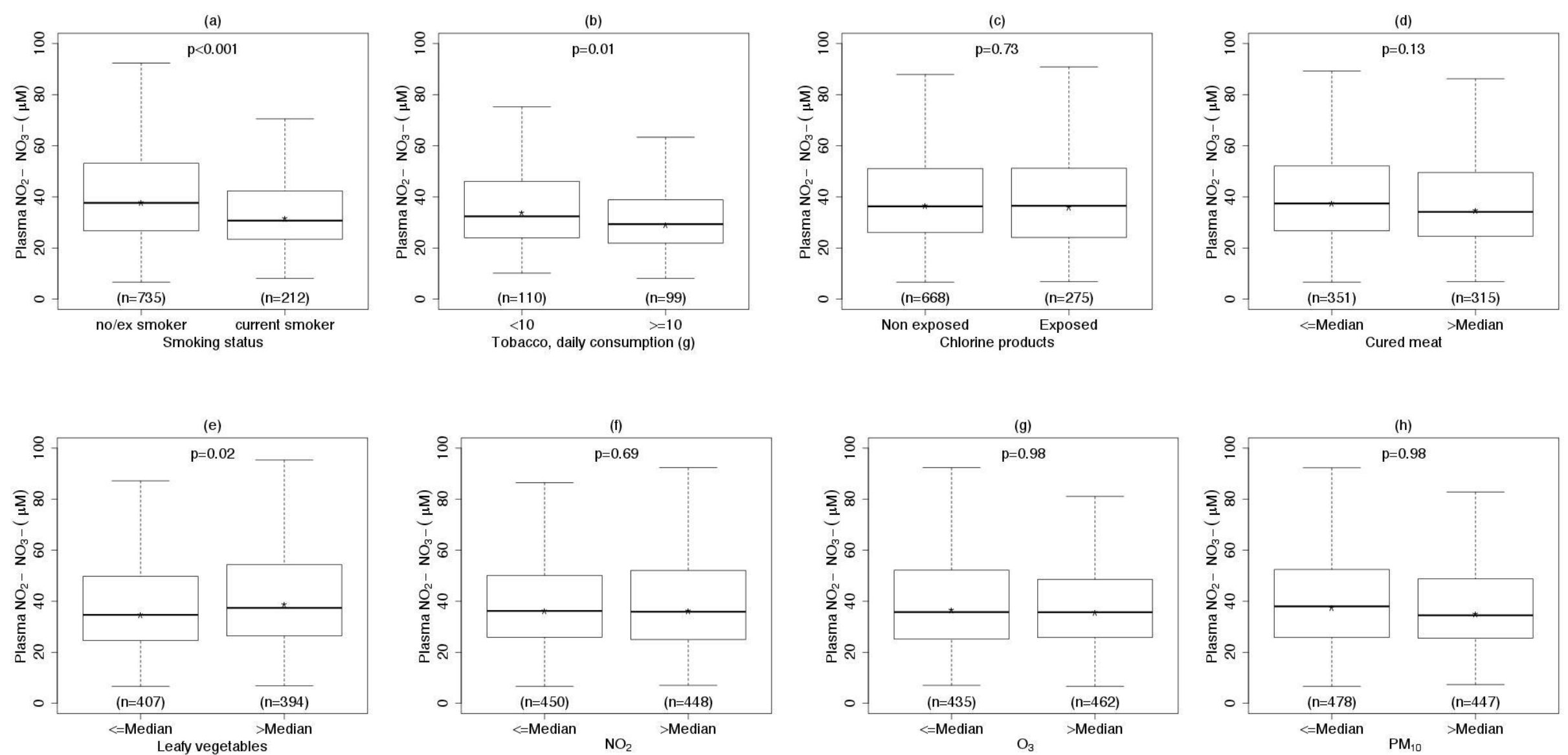
Figure A.3: Boxplots of total $\mathrm{NO}_{2}{ }^{-} / \mathrm{NO}_{3}{ }^{-}$level in $\mathrm{EBC}$ and smoking habits (a), tobacco daily consumption among smokers (b) and exposure to chlorine products (c). Whiskers correspond to $1.5^{*}$ interquartile range, the symbol * corresponds to the average $\mathrm{NO}_{2}{ }^{-} / \mathrm{NO}_{3}{ }^{-}$level in the group

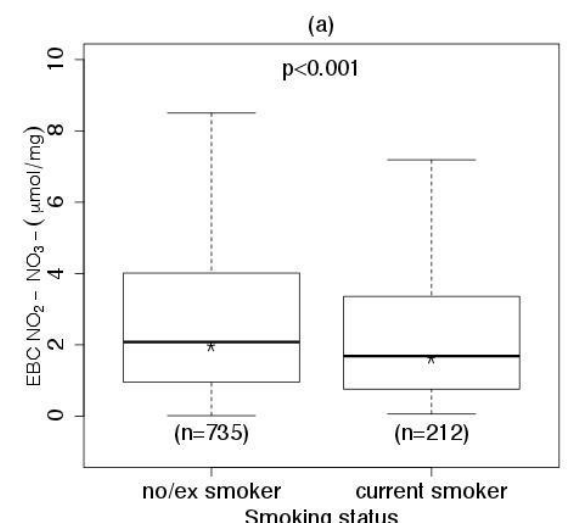

Smoking status

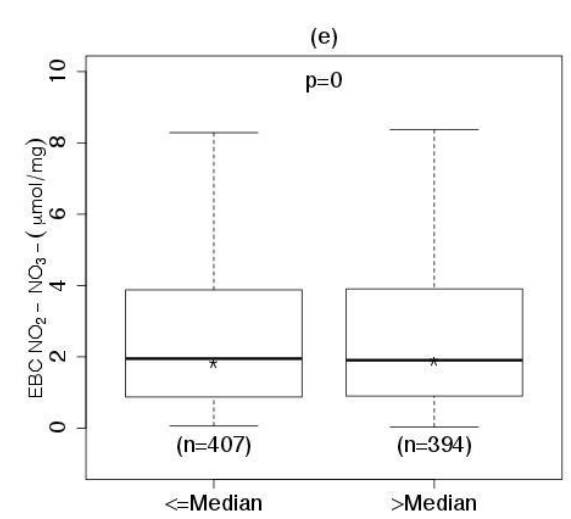

Leaty vegetables
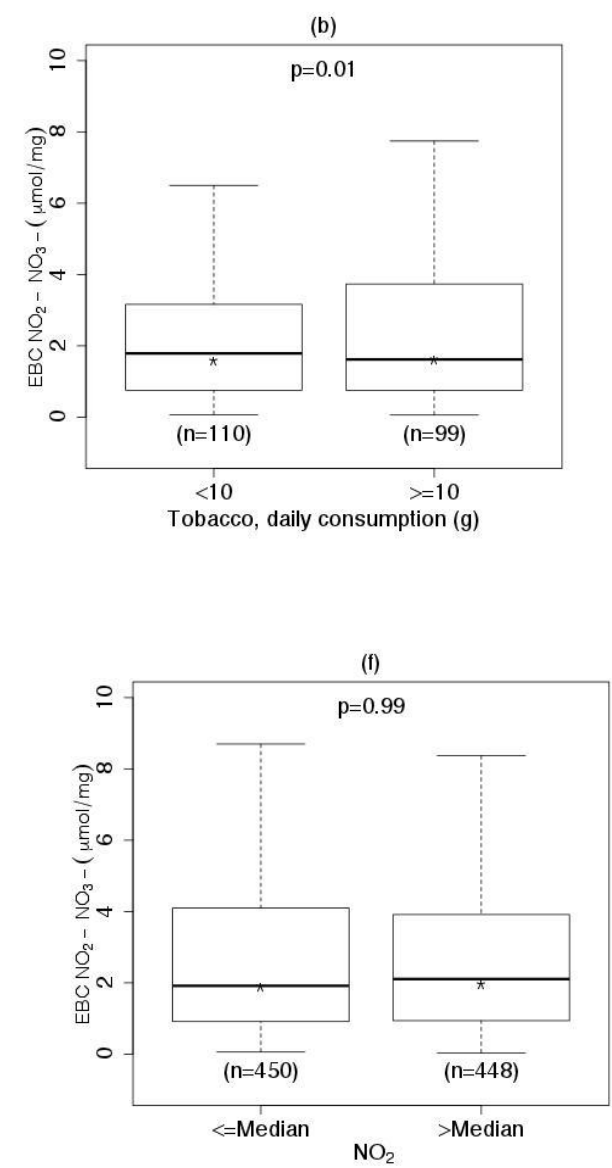
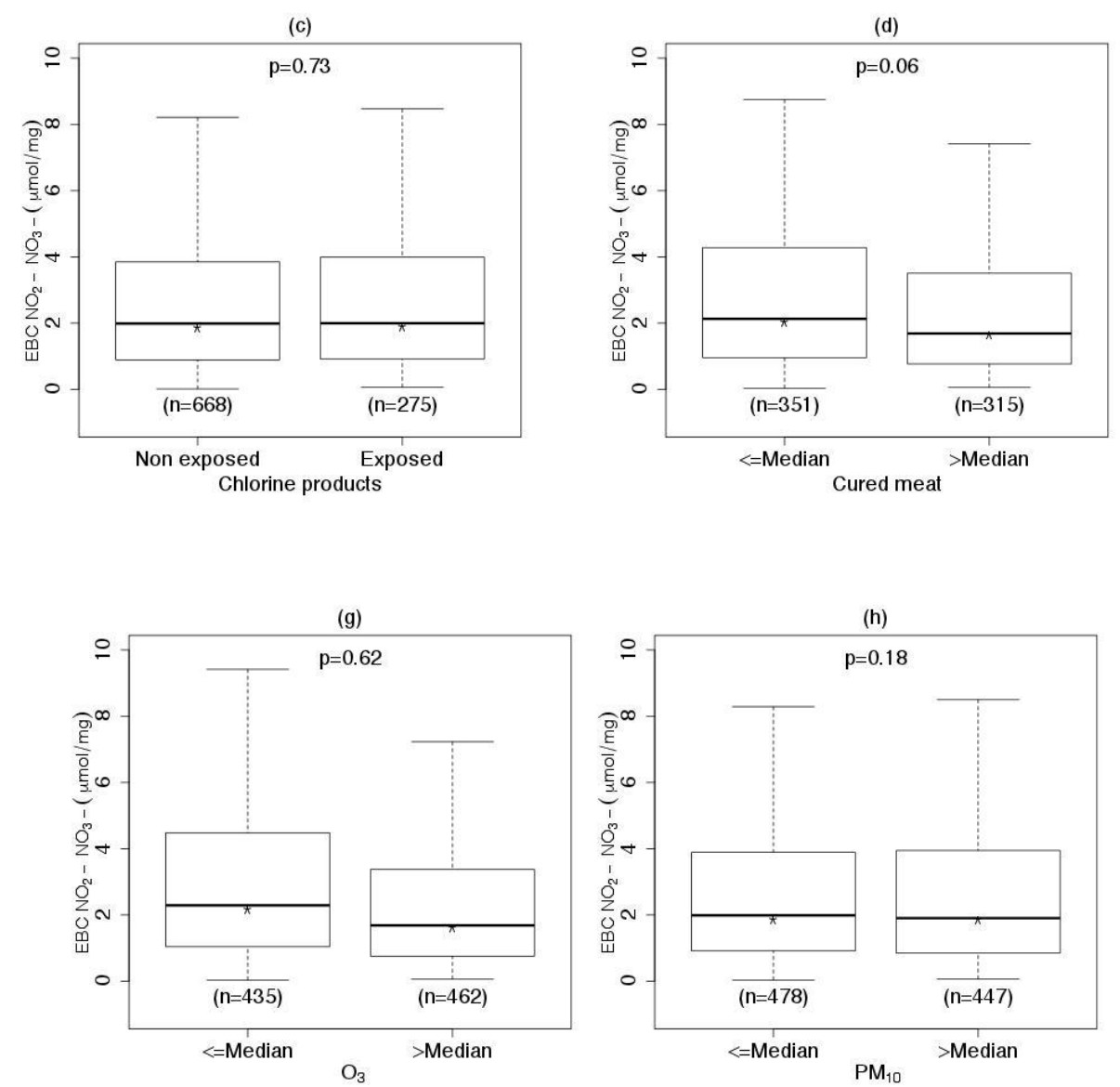


\section{Highlights}

- We studied associations of nitrite/nitrate level and four environmental exposures

- In plasma nitrite/nitrate level increased with consumption of leafy vegetables

- In EBC nitrite/nitrate level decreased with exposure to ambient ozone.

- Tobacco smoke was associated with lower plasma and EBC nitrite/nitrate level

- Environmental exposures may modify plasma and EBC nitrite/nitrate levels 